\title{
Study Regarding the in Vitro Regeneration and Use Perspectives in Some Valeriana officinalis L. Genotypes
}

\author{
Dorin D. Camen ${ }^{1}$, Carmen G. Beinsan ${ }^{1} \&$ Radu L. Sumalan ${ }^{1}$ \\ ${ }^{1}$ Plant Physiology Department, Banat's University of Agricultural Science and Veterinary Medicine Timisoara, \\ Romania \\ Correspondence: Dorin D. Camen, Plant Physiology Department, Banat's University of Agricultural Science and \\ Veterinary Medicine Timisoara, Romania. E-mail: camendorin@yahoo.com
}

Received: May 9, 2012 Accepted: May 21, 2012 Online Published: July 27, 2012

doi:10.5539/jas.v4n8p222 URL: http://dx.doi.org/10.5539/jas.v4n8p222

\begin{abstract}
The purpose of the researchers was to evaluate the regeneration possibilities of the species Valeriana officinalis L. from the point of view of "in vitro" cultivation of the species, as well as the influence of genotypes and of the culture environment on the "in vitro" reaction of the species. The biological material used in the process of research was made up of cultivated and spontaneous forms of Valeriana officinalis L. present in the collection of the University of Agricultural Science and Veterinary Medicine in Cluj-Napoca, Romania. The studied genotypes were: Valeriana officinalis, Volgensis, Sambucifolia, Collina, Rossica, Magurele 100, Moscova 835 with different geographical provenience. For the "in vitro" culture of Valeriana officinalis L. explants stemming from 2-4 week-old plants were used. The explants were formed of fragments of stem measuring $0.2-0.5 \mathrm{~cm}$ and leaf fragments $0.4-0.6 \mathrm{~cm}$ in length and $0.3-0.5 \mathrm{~cm}$ wide. The results obtained were different, according to the hormone balance: callus or direct risogenesis from the inoculated explants. Also we tested the regenerative possibilities from cell suspension from callus and roots with future possibilities for volatile oils extraction from in vitro suspension. The culture environment used was Murashige-Skoog, 1962, with different hormonal variations as follows: $\mathrm{V}_{0}-\mathrm{Mt}$. Murashige-Skoog culture media; $\mathrm{V}_{1}-10 \mathrm{mg} / \mathrm{L}$ naftalen acetic acid (NAA) and $0.1 \mathrm{mg} / \mathrm{L}$ benzyl amino purine (BAP); $\mathrm{V}_{2}-1 \mathrm{mg} / \mathrm{L} \mathrm{NAA}$ and $1 \mathrm{mg} / \mathrm{L} \mathrm{BAP} ; \mathrm{V}_{3}-0.1 \mathrm{mg} / \mathrm{L}$ NAA and $1 \mathrm{mg} / \mathrm{L}$ BAP.
\end{abstract}

Keywords: Valerian, "in vitro", hormones, auxines, citokinines

\section{Introduction}

The employment of plants in the prevention and treatment of diseases represents the oldest form of known medicine. The experts in the field state that the natural balance of the active elements contained in plants is far less damaging and even more efficient than the synthesis-based medications with a single active ingredient. Nowadays, around the world, about half of the pharmaceutical products are based upon medicinal plants, or have in their composition active ingredients extracted from plants (such as alkaloids, glycosides, essential oils, etc.). (Ciulei et al., 1993; Goina et al., 1967).

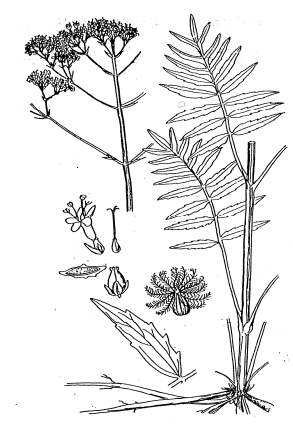

Figure 1. Valeriana officinalis L.

One of the plants which ensure the raw material for getting a wide range of drugs is the species Valeriana 
officinalis L. (Figure1). (www.ro.wikipedia.org/wiki/Valerian\%C4\%83, http//www.eukarya.ro/taxon/10210).

The therapeutic properties of valerian are known since ancient times. Nowadays, the employment of valerian as a sedative and antispasmodic is extending even more. The combination of active elements in the raw material (root stock and roots) of valerian (volatile oils, iridoids, acids, alkaloids, etc) exerts a sedative action on the nervous system and the heart.

The valerian is appreciated as being one of the most important sedatives for the nervous system. It is present in the composition of a large number of extremely important drugs, essential for human health, covering a large spectrum of medical conditions: psychic disorders, heart diseases, conditions of the central nervous system, digestive and muscular diseases, etc. We can also mention other fields where valerian is used: in the food industry (giving flavour to alcoholic and soft drinks, in the preparation of certain meat products, etc.), in the perfume and cosmetic industry, as a decorative plant (some species have red, violet or white flowers), etc. (http://www.eplante.ro/plante-a-z/odolean-Valeriana-officinalis.html, http://www.herbmed.org/\#param.wapp?sw_page=viewHerb\%3FherbID\%3D133 ).

The culture of different explants which contain differentiated cells on aseptic environments rich in auxines leads to cellular mass forming, having an uniform histologic structure. This cellular mass is called callus and it can be cultivated and multiplied through fragmentation and green environmental transfer, maintaining in this way the vitality of the cells and their division capacity. If it's not cultivated on time, the callus grows old and changes it's colour pursuant to metabolite accumulation. According to Nabors, 1983 the callus can be a recuperative type when it leads to complete plant formation or a non-recuperative type when it grows abundantly and it regenerates either roots, either buds, but never complete plants.

The non-recuperative callus has a loose consistency, is brittle, the cells being easily dispearseable. Being cultivated on an environment with an over the unit cytokinine/auxine rate, the callus can produce shoots through indirect organogenesis. However we notice that in high concentrations all the auxines can produce callus induction, but in some cases we need less cytokinine for the callus to start forming. This happens because some auxines, when in dense quantities, they can stop the physiologic and morphologic proceses that take place in the plant's cells.

Specific differences exist in the in vitro response of genetically diverse genotypes. Distinctions can be made among cultivars for their callus growth response, ability to initiate shoots and roots, and regeneration potential. Varieties and breeding lines have been identified for their ability to yield numerous regenerated plantlets.

The identification of specific genotypes that are capable of rapid callus production and high rates of plantlet regeneration is an important step toward the application of tissue culture techniques to agriculture (Goldstein \& Kronstad, 1985).

\section{Materials and Methods}

The biological material used in the process of research was made up of cultivated and spontaneous forms of Valeriana officinalis L. present in the collection of the University of Agricultural Science and Veterinary Medicine in Cluj-Napoca, Romania.

The studied genotypes were: Valeriana officinalis, Volgensis, Sambucifolia, Collina, Rossica, Magurele 100, Moscova 835.

The results obtained were different, according to the hormone balance: callus or direct risogenesis from the inoculated explants.

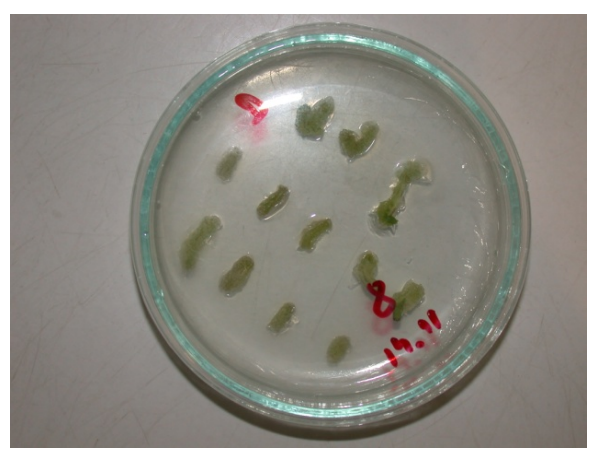

Figure 2. Explants inoculation

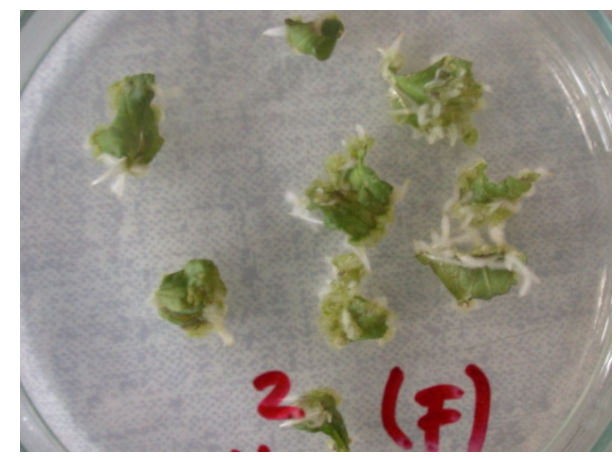

Figure 3. "In vitro" reaction initiation 
Table 1. MS culture media composition (Murashige \& Skoog, 1962)

\begin{tabular}{|c|c|c|c|}
\hline \multicolumn{4}{|c|}{ Constituents } \\
\hline \multicolumn{2}{|c|}{ Macroelements (mg/L) } & \multicolumn{2}{|c|}{ Microelements (mg/L) } \\
\hline $\mathrm{KNO}_{3}$ & 1900 & $\mathrm{CuSO}_{4} \times 5 \mathrm{H}_{2} \mathrm{O}$ & 0.025 \\
\hline $\mathrm{NH}_{4} \mathrm{NO}_{3}$ & 1650 & $\mathrm{CoCl}_{2} \times 6 \mathrm{H}_{2} \mathrm{O}$ & 0.025 \\
\hline $\mathrm{CaCl}_{2} \times 2 \mathrm{H}_{2} \mathrm{O}$ & 440 & $\mathrm{FeSO}_{4} \times 7 \mathrm{H}_{2} \mathrm{O}$ & 27.8 \\
\hline $\mathrm{MgSO}_{4} \times 7 \mathrm{H}_{2} \mathrm{O}$ & 370 & $\mathrm{Na}_{2}$ EDTA & 37.3 \\
\hline $\mathrm{KH}_{2} \mathrm{PO}_{4}$ & 170 & \multicolumn{2}{|c|}{ Vitamins $(\mathrm{mg} / \mathrm{L})$} \\
\hline $\mathrm{ZnSO}_{4} \times 7 \mathrm{H}_{2} \mathrm{O}$ & 8.6 & myo-Inositol & 100 \\
\hline $\mathrm{MnSO}_{4} \times 4 \mathrm{H}_{2} \mathrm{O}$ & 22.3 & Thiamina $\mathrm{HCl}$ & 0.1 \\
\hline $\mathrm{H}_{3} \mathrm{BO}_{3}$ & 6.2 & Piridoxina $\mathrm{HCl}$ & 0.5 \\
\hline KI & 0.83 & Acid nicotinic & 0.5 \\
\hline \multirow[t]{4}{*}{$\mathrm{Na}_{2} \mathrm{MoO}_{4} \times 2 \mathrm{H}_{2} \mathrm{O}$} & 0.25 & Glicina & 2 \\
\hline & & Saccharose & 30000 \\
\hline & & Agar & 6700 \\
\hline & $\mathrm{pH}$ & $5.4-5.6$ & \\
\hline
\end{tabular}

The culture environment used was Murashige-Skoog, 1962, (Table 1), with different hormonal variations as follows: $\mathrm{V}_{0}-$ Mt. Murashige-Skoog environment; $\mathrm{V}_{1}-10 \mathrm{mg} / \mathrm{L}$ ANA and $0.1 \mathrm{mg} / \mathrm{L} \mathrm{BA} ; \mathrm{V}_{2}-1 \mathrm{mg} / \mathrm{L}$ ANA and $1 \mathrm{mg} / \mathrm{L} \mathrm{BA} ; \mathrm{V}_{3}-0.1 \mathrm{mg} / \mathrm{L}$ ANA and $1 \mathrm{mg} / \mathrm{L}$ BA. The steps of "in vitro" cultivation: A. The sterilization of the vegetal material was performed through the immersion for 10 minutes in a solution of sodium hypochlorite (10 $\%$ ) followed by three-minute washings in sterile distilled water; B. The inoculation of the plants (Figure 2) was done immediately after they have been measured with sterile instruments; $\mathrm{C}$. The incubation of the explants (Figure 3) was done in a grow room under controlled conditions of temperature $\left(25^{\circ} \mathrm{C}\right.$ by day and $22^{\circ} \mathrm{C}$ by night) and illumination (photoperiod of 16 hours of light and 8 hours of darkness). During the first days after inoculation a selection was made, removing the infested containers.

In general, the possibility of applying such methods depends on the species, the donor material, age of the explants or the environment's formula (Lührs \& Lörz, 1987; Nabors et al., 1983; Popelka \& Altpeter, 2001; Maës et al., 1996; Dahleen, 1999), (Lührs \& Lörz, 1987; Barro et al., 1999, Thomas \& Scott, 1985; Maës et al., 1996, as cited in Gana, 2010).

\section{Results}

Four genotypes of Valeriana officinalis L. have been used: Volgensis x Magurele 100, Sambucifolia, V. officinalis - Volgensis. Also, we have used two types of explants: explants prevailed from the stem and explants prevailed from the leaf blades (about $0.5 \mathrm{~cm}$ in length). Inside each variant a spontaneous variant of $V$. officinalis was chosen for comparison with the other genotypes.

Table 2. Variance analysis for $\mathrm{V}_{0}$ hormonal variant at 14 days from inoculation in 4 valeriana studied genotypes using leaf explants

\begin{tabular}{cccccc}
\hline The variation source & SP & GL & S $^{2}$ & F & F crit \\
\hline Genotypes & 47.51 & 3 & 15.83 & 0.78 & 4.75 \\
Repetitions & 32.08 & 2 & 16.04 & & \\
Error & 120.42 & 6 & 20.07 & & \\
Sum & 200.02 & 11 & & & \\
\hline
\end{tabular}


Applying the 'ANOVA' test (Ciulca, 2006) for the hormonal variation $\mathrm{V}_{0}$ there are no significant variations to be noted in the results, $\left(\mathrm{F}=0.78 \leq \mathrm{F}_{\text {crit }}=4.75\right)$ between the valerian genotypes experimented on in order to determine the reaction to the "in vitro" culture (Table 2). This fact can be due to the culture environment used, one without growth hormones.

Table 3. The significance of differences between different genotypes regarding the reaction at "in vitro" culture on $\mathrm{V}_{1}$ hormonal variant on 14 days from inoculation for leaf explants

\begin{tabular}{|c|c|c|c|c|}
\hline Genotype & \multicolumn{2}{|c|}{ Mean $(\%)$} & \multirow{2}{*}{$\frac{\text { Mean difference }}{10.61}$} & \multirow{2}{*}{$\frac{\text { Significance }}{* * *}$} \\
\hline Volgensis - Volgensis X Magurele 100 & 88.20 & 77.59 & & \\
\hline Volgensis - Sambucifolia & 88.20 & 78.51 & 9.69 & $* *$ \\
\hline Volgensis - V.officinalis & 88.20 & 79.86 & 8.34 & $* *$ \\
\hline V.officinalis - Volgensis X Magurele 100 & 79.86 & 77.59 & 2.27 & - \\
\hline V.officinalis - Sambucifolia & 79.86 & 78.51 & 1.35 & - \\
\hline Sambucifolia - Volgensis X Magurele 100 & 78.51 & 77.59 & 0.92 & - \\
\hline $\mathrm{DL}_{5 \%}$ & $\mathrm{DL}_{1 \%}$ & $\mathrm{DL}_{0.1 \%}$ & & \\
\hline 4 & 5.56 & 9.71 & & \\
\hline
\end{tabular}

From the comparison of the genotypes from the point of view of their capacity to respond to the conditions of "in vitro" conditions of the explants prevailed from leaves, 14 days after the inoculation on the hormonal variant $\mathrm{V}_{1}$ we have observed the fact that all genotypes react positively to the modern possibilities available for cultivations under controlled conditions. Yet, we can remark the Volgensis genotype with an over 88\% response percentage. The genotype $V$. officinalis used for comparison registered a response rate of $79.86 \%$ (Table 3 ).

Table 4. The significance of differences between different genotypes regarding the reaction at "in vitro" culture on $\mathrm{V}_{2}$ hormonal variant on 14 days from inoculation for leaf explants

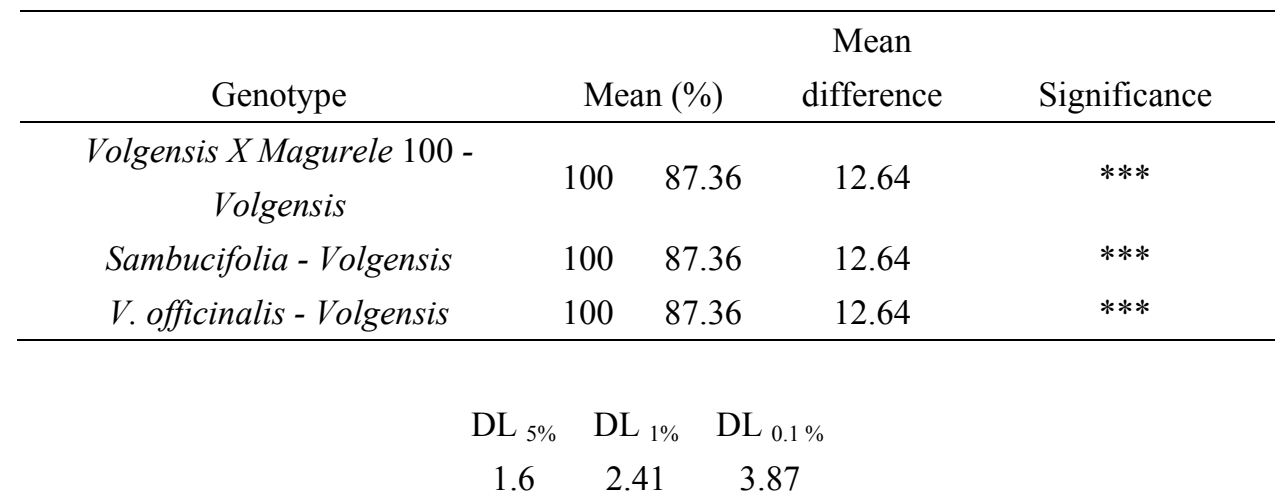

After the comparative analysis of the four genotypes of valerian under the aspect of the response of the leaf explants after 14 days after inoculation on the hormonal variant $\mathrm{V}_{2}$ it was noted that valerian is a species which can be cultivated using the modern possibilities made available by the cell and tissue cultures. The genotype Volgensis X Magurele 100 was outstanding with a maximum response percentage out of the total number of inoculated explants (Table 4). 
Table 5. The significance of differences between different genotypes regarding the reaction at "in vitro" culture on $\mathrm{V}_{3}$ hormonal variant on 14 days from inoculation for leaf explants

\begin{tabular}{ccccc}
\hline Genotype & \multicolumn{2}{c}{ Mean (\%) } & Mean difference & Significance \\
\hline Volgensis X Magurele 100 - Volgensis & 100 & 14.60 & 85.39 & $* * *$ \\
Volgensis X Magurele 100 - Sambucifolia & 100 & 85.92 & 85.39 & $* * *$ \\
Volgensis X Magurele 100 - V. officinalis & 100 & 100 & 0 & - \\
V. officinalis - Sambucifolia & 100 & 14.60 & 85.39 & $* * *$ \\
V. officinalis - Volgensis & 100 & 85.92 & 14.07 & - \\
Sambucifolia - Volgensis & 85.92 & 14.60 & 71.32 & $* * *$ \\
\hline
\end{tabular}

$$
\begin{array}{ccc}
\mathrm{DL}_{5 \%} & \mathrm{DL}_{1 \%} & \mathrm{DL}_{0.1 \%} \\
14.67 & 22.22 & 35.7
\end{array}
$$

From the comparison of the genotypes from the point of view of the "in vitro" culture conditions of the explants prevailed from leaves 14 days after the inoculation on the hormonal variant $\mathrm{V}_{3}$ (which implies a hormonal infusion of auxines and cytokines) we observed that each genotype has a positive reaction to the modern possibilities of cultivation under controlled conditions. Yet, the genotypes Volgensis X Magurele 100 and $V$. officinalis (the genotype for comparison) have given a $100 \%$ response, while the Volgensis genotype has had the lowest response rate of $14.6 \%$ (Table 5).

Table 6. Variance analysis for $\mathrm{V}_{0}$ hormonal variant at 14 days from inoculation in 4 valeriana studied genotypes using stem explants

\begin{tabular}{cccccc}
\hline The variation source & SP & GL & S $^{2}$ & F & F crit \\
\hline Genotypes & 480.72 & 3 & 160.24 & 3.37 & 4.75 \\
Repetitions & 120.35 & 2 & 60.17 & & \\
Error & 284.49 & 6 & 47.41 & & \\
Sum & 885.58 & 11 & & & \\
\hline
\end{tabular}

After applying the variance analysis test for the "in vitro" culture conditions we have observed the fact that there are no significant differences between the valerian genotypes used, taking into account the response of the stem explants cultivated on the $\mathrm{V}_{\mathrm{O}}$ hormonal variant (MS environment without a hormonal input). The $\mathrm{F}$ test confirms this theory $\left(\mathrm{F}=17.68 \leq \mathrm{F}_{\text {critic }}=4.75\right)$ (Table 6). We can also observe the fact that exactly like in the case of the leaf explants, the $\mathrm{V}_{\mathrm{O}}$ hormonal variant does not trigger differences between genotypes.

Table 7. The significance of differences between different genotypes regarding the reaction at "in vitro" culture on $\mathrm{V}_{1}$ hormonal variant on 14 days from inoculation for stem explants

\begin{tabular}{ccccc}
\hline Genotype & \multicolumn{2}{c}{ Mean (\%) } & Mean difference & Significance \\
\hline Sambucifolia - Volgensis & 79.12 & 55.80 & 23.31 & $* * *$ \\
Sambucifolia - V. officinalis & 79.12 & 66.38 & 12.73 & $* *$ \\
Sambucifolia - Volgensis X Magurele 100 & 79.12 & 69.79 & 9.32 & $*$ \\
Volgensis X Magurele 100 - Volgensis & 69.79 & 55.80 & 13.99 & $* *$ \\
Volgensis X Magurele 100 - V. officinalis & 69.79 & 66.38 & 3.40 & - \\
V. officinalis - Volgensis & 66.38 & 55.80 & 10.58 & - \\
\hline
\end{tabular}

$$
\mathrm{DL}_{5 \%} \quad \mathrm{DL}_{1 \%} \quad \mathrm{DL}_{0.1 \%}
$$




\section{$6.39 \quad 9.64 \quad 15.49$}

After the comparative analysis of the four genotypes of valerian from the point of view of the explants prevailed from the stem, 14 days after the inoculation on the hormonal variant $V_{1}$ it was ascertained that valerian is a species which can be cultivated by using the modern possibilities made available by the cell and tissue cultures. The genotype Sambucifolia was outstanding with a response rate of $79.12 \%$ out of the total number of inoculated explants (Table 7). Yet, the response percentage is slightly lower than the one obtained from the leaf explants.

Table 8 . The significance of differences between different genotypes regarding the reaction at "in vitro" culture on $\mathrm{V}_{2}$ hormonal variant on 14 days from inoculation for stem explants

\begin{tabular}{ccccc}
\hline Genotype & \multicolumn{2}{c}{ Mean (\%) } & Mean difference & Significance \\
\hline V. officinalis - Volgensis X Magurele 100 & 100 & 36.92 & 63.07 & $* * *$ \\
V. officinalis - Volgensis & 100 & 51.85 & 48.14 & $* * *$ \\
V. officinalis - Sambucifolia & 100 & 100 & 0.00 & - \\
Sambucifolia - Volgensis X Magurele 100 & 100 & 36.92 & 63.07 & $* * *$ \\
Sambucifolia - Volgensis & 100 & 51.85 & 48.14 & $* * *$ \\
Volgensis - Volgensis X Magurele 100 & 51.85 & 36.92 & 14.92 & \\
\hline & & &
\end{tabular}

From the comparison of the genotypes from the point of view of their capacity to respond to the "in vitro" culture conditions of the explants prevailed from the stem, 14 days after the inoculation on the hormonal variant $\mathrm{V}_{2}$ (which implies a hormonal infusion of auxines and cytokines) we observed that each genotype has a positive reaction to the modern possibilities of cultivation under controlled conditions. Yet, the genotypes Volgensis $X$ Magurele 100 and $V$. officinalis (the genotype for comparison), Sambucifolia with a 100\% response stand out, while the Magurele 100 genotype recorded the lowest response rate, 36.92\% (Table 8).

Table 9. The significance of differences between different genotypes regarding the reaction at "in vitro" culture on $\mathrm{V}_{3}$ hormonal variant on 14 days from inoculation for stem explants

\begin{tabular}{ccccc}
\hline Genotype & \multicolumn{2}{c}{ Mean (\%) } & Mean difference & Significance \\
\hline Sambucifolia - Volgensis X Magurele 100 & 100 & 63.43 & 36.56 & $* * *$ \\
Sambucifolia - Volgensis & 100 & 77.46 & 22.54 & $* *$ \\
Sambucifolia - V. officinalis & 100 & 84.72 & 15.27 & $* * *$ \\
V. officinalis - Volgensis X Magurele 100 & 84.72 & 63.43 & 21.28 & $* * *$ \\
V. officinalis - Volgensis & 84.72 & 77.46 & 7.26 & - \\
Volgensis - Volgensis X Magurele 100 & 77.46 & 63.43 & 14.02 & $*$ \\
\hline
\end{tabular}

$$
\begin{array}{ccc}
\text { DL }_{5 \%} & \text { DL }_{1 \%} & \text { DL }_{0.1 \%} \\
9.42 & 14.24 & 22.88
\end{array}
$$

After the comparative analysis of the four genotypes of valerian from the point of view of the explants prevailed from the stem, 14 days after the inoculation on the hormonal variant $V_{3}$ it was ascertained that valerian is a species which can be cultivated by using the modern possibilities made available by the cell and tissue cultures. The genotype Sambucifolia was outstanding with a response rate of $100 \%$ out of the total number of inoculated explants (Table 9). Yet, the response percentage is slightly lower than the one obtained from the leaf explants.

\section{Discussion}

If we refer to the variation of the results for the $V_{O}$ hormonal variant for leaf explants, after 14 days from the inoculation there are no significant differences between genotypes. 
Numerous factors are reported to influence the success of in vitro propagation of different medicinal plants and therefore, it is unwise to define any particular reason for the general micro propagation of medicinal plants (Rout et al., 2000).

The effective response of plantlets to $1 \mathrm{mg} / \mathrm{L}$ BAP during the micro propagation of other Valerianaceae species (Kaur et al., 1999) and other medicinal plants such as Echinacea purpurea L. (Koroch et al., 2002) has also been reported. In respect of rooting of shoots, we observed that rooting had the better response on MS medium without any PGRs compared to MS medium supplemented with $2 \mathrm{mg} / \mathrm{L}$ IBA after 21 days. It seems that rooting in absence of auxins may be attributed to endogenous auxin hormones in the plant. We also found similar results to other medicinal plants. (Sudhersan \& Hussan, 2003; Lu, 2005).

From the comparison of the genotypes regarding the capacity of response to the "in vitro" culture conditions of the leaf explants, 14 days after the inoculation, we noticed that in the $V_{1}$ hormonal variant, all genotypes react positively to the modern cultivation possibilities in terms of controlled conditions. However, we can notice the Volgensis genotype, having an over $88 \%$ response rate.

Rani et al., (2003), reported that the best medium for callus formation from hypocotyl, cotyledon and root explants of Withania somnifera L. achieved on MS medium supplemented with $0.2 \mathrm{mg} / \mathrm{L} \mathrm{Kin}$ and $2 \mathrm{mg} / \mathrm{L} 2.4-\mathrm{D}$ as $100 \%$. In another study, 2.4-D (0.5 to $2 \mathrm{mg} / \mathrm{L})$ introduced as one of the most important auxins in callus induction of $V$. edulis sp. Procea (Castillo et al., 2000) and Leonurus heterophylus (Yang et al., 2008). In the current study, combination of $\mathrm{Kin}(0.1 \mathrm{mg} / \mathrm{L})$ and $2.4-\mathrm{D}(2 \mathrm{mg} / \mathrm{L})$ for callus induction from leaf and root explants was more effective than other concentrations which were in agreement with these reports.

In the $\mathrm{V}_{2}$ hormonal variant we notice that the valerian is a species that can be cultivated using the modern possibilities offered by the cell and tisue cultures. We can distinguish the Volgensis X Magurele 100 genotype with a maximum response rate from the total number of explants that were inoculated after 14 days using leaf explants.

Somaclonal variation in regenerated plant genotypes has been described repeatedly in other plant tissue culture literature (Larkin et al., 1984). From the genotypes comparison regarding the response capacity to the "in vitro" culture conditions of the leaf explants, 14 days after the $\mathrm{V}_{3}$ hormonal variant inoculation (meaning a hormonal input of auxins and cytokines) we notice the Volgensis X Magurele and $V$. officinalis (a comparison genotype), having a $100 \%$ response rate, while the Volgensis genotype registers the lowest response rate $14.6 \%$.

Abdi and Khosh-Khui, 2007, stated that, the best results regarding shoot regeneration of $V$. officinalis was occurred on medium containing $1 \mathrm{mg} / \mathrm{L} \mathrm{BAP}$ and also the numbers of shoots induced per explants were higher in the presence of $1 \mathrm{mg} / \mathrm{L} \mathrm{BAP}$ in leaf explants. They found that among the cytokinins that they tested, BAP gave better result compared to Kin in shoot induction.

As a result of the variance analysis for the reaction to the "in vitro" culture conditions we notice significant differences between the valerian genotypes used as a response to the stem explants, 14 days after the inoculation in the $\mathrm{V}_{\mathrm{O}}$ hormonal variant. After the comparative analysis of the four valerian genotypes regarding the response of the stem explants 14 days after the inoculation in the $\mathrm{V}_{1}$ hormonal variant, we can observe that the valerian is a species that can be cultivated using modern possibilities offered by cell and tisue culture. We can distinguish the Sambucifolia genotype with a $79.12 \%$ response rate.

Also, in other medicinal species (Lu et al., 2008; Peng et al., 2008). Mehrotra et al., (2008), stated that application of auxins such as IAA in low concentrations $(0.1 \mathrm{mg} / \mathrm{L})$ to the medium promoted production of hairy roots of Glycyrrhiza glabra.

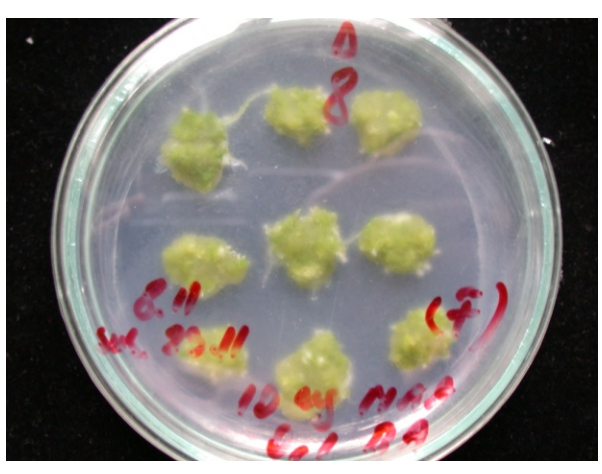

Figure 4. Callus "in vitro" reaction

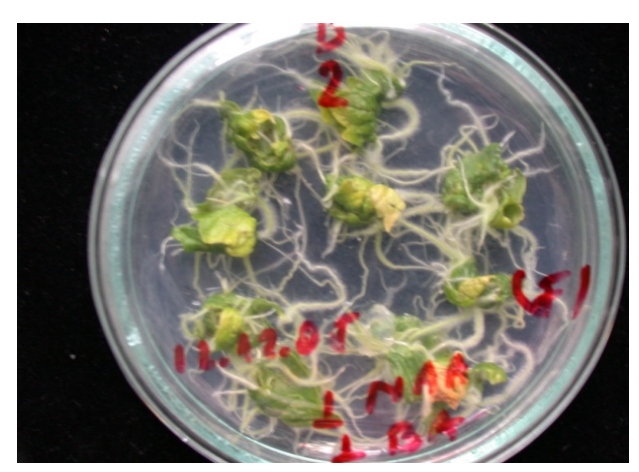

Figure 5. Rooting "in vitro" reaction 
After comparing the genotypes as for their response capacity to the "in vitro" culture conditions of the stem explants 14 days after the inoculation in the $\mathrm{V}_{2}$ hormonal variant (implying a hormonal input of auxines and cytokines) we can notice that all genotypes react positively to the modern cultivation possibilities under controlled conditions. However we can distinguish the Volgensis X Magurele, V. officinalis (a comparison genotype), Sambucifolia having a 100\% response rate. After comparing the four valerian genotypes concerning the stem explants 14 days after the inoculation process in the $\mathrm{V}_{3}$ hormonal variant we notice that the valerian is a species that can be cultivated using modern posibilities offered by the cell and tisue culture. We can distinguish the Sambucifolia genotype, having a 100\% response rate. According to the hormonal balance scale that has been used we acquired two types of reaction: callus and roots (direct organogenesis). We can exploit this in the future in order to obtain volatile oils through the "in vitro" cultivation techniques, being possible to obtain vegetal biomass under the form of roots (the organs where the volatile oils naturally accumulate to) or using the callus for the induction of suspended cells cultures using bioreactors (Figures 4 and 5).

This makes it interesting to study the possibility of producing secondary metabolites through plant cell and tissue culture (Becker et al., 1977). In the 1990s, increases in yield of valepotriates in transformed roots by A. rhizogenes in Valerianaceae were reported frequently (Gränicher et al., 1992 \& 1995; Banerjee et al., 1998; Caetano et al., 1999).

\section{References}

Abdi, G. H., \& Khosh, Khui. (2007). Shoot regeneration via direct organogenesis from leaf segments of Valerian (Valeriana officinalis L.). Int. J. Agric. Res., 2(10), 877-882.

Banerjee, S., Rahman, L., Uniyal, G. C., \& Ahuja, P. S. (1998). Enhanced production of valepotriates by Agrobacterium rhizogeneses induced hairy root cultures of Valeriana wallichii DC. Plant Sci., 131, 203-208.

Barro, F., Martin, A., Lazzeri, P. A., \& Barcelo, P. (1999). Medium optimization for efficient somatic embryogenesis and plant regeneration from immature inflorescences and immature scutella of elite cultivars of wheat, barley and tridordeum. Euphytica, 108, 161-167.

Becker, H., Schrall, R., \& Hartmann, W. (1977). Calluskulturen von Baldrian-Arten, 1. Mitt. Aniage einer Calluskutur von Valeriana wallichii DC. und erste analystische Untersuchungen. Arch Pharm., 310, 481-484.

Caetano, C. L., Charlwood, B. V., \& Gahan, P. B. (1999). The localization and accumulation of valepotriates in hairy roots of Valerianella discoidea (L.) Loisel. Phytochem Anal., 10, 181-186.

Castillo, P., Ma'rquez, J., Rubluo, A., Herna'ndez, G., \& Lara, M. (2000). Plant regeneration from callus and suspension cultures of Valeriana edulis ssp. procera via simultaneous organogenesis and somatic embryogenesis. Plant Sci., 151, 115-119.

Ciulca, S. (2006). Elemente de genetica cantitativa si genetica populatiilor, Ed. Agroprint, Timisoara.

Ciulei, I., Grigorescu, E., \& Stanescu, U. (1993). Plante medicinale: fitochimie, fitoterapie. (Medicinal plants, phytochemistry, phytoterapy.) Medicinal Press, Bucharest, pp. 210-235.

Dahleen, L. S. (1999). Donor-plant environment effects on regeneration from barley embryo-derived callus. Crop Science, 39, 682-685.

Gana, A. S. (2010). The role of synthetic growth hormones in crop multiplication and improvement. African Journal of Biotechnology, 10(51), 10330-10334.

Goina, T., Constantinescu, E., \& Ciulei, I. (1967). Farmacognozie, Ed. Didactica si Pedagogica, Bucuresti.

Goldstein, C. S., \& KronstaW, E. D. (1985). Tissue culture and plant regeneration from immature embryo explants of Barley. Hordeum vulgate, Theor Appl Genet, 71, 631-636.

Gränicher, F., Christen, P. H., \& Kapétanidis, I. (1992). High-yield production of valepotriates by hairy root cultures of Valeriana officinalis L. var. sambucifolia Mikan. Plant Cell Rep., 11, 339-342.

Gränicher, F., Christen, P. H., \& Kapétanidis, I. (1995). Production of valepotriates by hairy root cultures of Centranthus ruber DC. Plant Cell Rep., 14, 294-298.

Kaur, R., Sood, M., Chander, S., Mahajan, R., Kumar, V., \& Shama, D. R. (1999). In vitro propagation of Valeriana jatamansi. Plant Cell. Tiss. Org. Cult., 59, 227-229.

Koroch, A. R., Juliani, H. R., Kapteyn, J., \& Simon, J. E. (2002). In vitro regeneration of Echinacea purpurea from leaf explants. Plant Cell. Tiss. Org. Cult., 69, 79-83. 
Larkin, P. J., Ryan, S. A., Bretell, R. I. S., \& Scowcroft, W. R. (1984). Heritable somaclonal variation in wheat. Theor. Appl. Genet., 67, 443-455.

Lu, M. C. (2005). Micropropagation of Vitis thunbergii Sieb., a medicinal herb through high-frequency shoots tip culture. Sci. Hort., 107, 64-69.

Lu, H. Y., Liu, J. M., Zhang, H. C., Yin, T., \& Gao, S. L. (2008). Ri-mediated transformation of Glycyrrhiza uralensis with a squalene synthase gene (GuSQS1) for production of Glycyrrhizin. Plant Mol. Biol. Rep., 26, $1-11$.

Lührs, R., \& Lörz, H. (1987). Plant regeneration in vitro from embryogenic cultures of spring- and winter-type barley (Hordeum vulgare L.) varieties. Theoretical and Applied Genetics, 75, 16-25.

Maës, O. C., Chibbar, R. N., Caswell, K., Leung, N., \& Kartha, K. K. (1996). Somatic embryogenesis from isolated scutella of wheat: effects of physical, physiological and genetic factors. Plant Science, 121, 75-84.

Mehrotra, S., Kukreja, A. K., Khanuja, S. P. S., \& Mishra, B. N. (2008). Genetic transformation studies and scale up of hairy root culture of Glycyrrhiza glabra in bioreactor. Electron. J. Biotechnol., 11(2), 1-7.

Murashige, T., \& Skoog, F. (1962). A revised medium for rapid growth and bioassays with tobacco tissue cultures, Physiol. Plant., 15, 473-497.

Nabors, M. W., Heyser, J. W., Dykes, T. A., \& DeMott, K. J. (1983). Longduration, high-requency plant regeneration from cereal tissue cultures. Planta, 157, 385-391.

Peng, C. X., Gong, J. S., Zhang, X. F., Zhang, M., \& Zheng, S. Q. (2008). Production of gastrodin through biotransformation of p-hydroxybenzyl alcohol using hairy root cultures of Datura tatula L. Afr. J. Biotechnol., 7(3), 211-216.

Popelka, J. C., \& Altpeter, F. (2001). Interactions between genotypes and culture media components for improved in vitro response of rye (Secale cereale L.) inbred lines. Plant Cell Reports, 20, 575-582.

Rani, Gita, Virk, G. S., \& Avinash, Nagpal. (2003). Callus induction and plantlet regeneration in Withania somnifera (L.) dunal. In Vitro Cellular \& Developmental Biology. Plant., 39(5), 468.

Rout, G. R., Samantaray, S., \& Das, P. (2000). In vitro manipulation and propagation of medicinal plants. Biotechnol Adv., 18(2), 91-120.

Sudhersan, C., \& Hussan, J. (2003). In vitro clonal propagation of a multipurpose Tree, Ziziphus spina-christi (L). Desf. Turk. J. Bot., 27, 167-171.

Thomas, M. R., \& Scott, K. J. (1985). Plant regeneration by somatic embryogenesis from callus initiated from immature embryos and immature inflorescences of Hordeum vulgare. Journal of Plant Physiology, 121, 159-169.

Yang, J., Gong, Z. C., \& Tan, X. (2008). Induction of callus and extraction of alkaloid from Yi Mu Cao (Leonurus heterophylus Sw.). Culture. Afr. J. Biotechnol., 7(8), 1157-1162. 